\title{
Implementation of Staff Recruitment Policies and Diversity Management in Universities in Central Uganda
}

\author{
Edith Namutebi ${ }^{1}$ \\ ${ }^{1}$ Mutesa I Royal University [E-mail: edithnamutebi29@gmail.com]
}

\begin{abstract}
Universities in Central Uganda exhibit shortfalls in the area of staff diversity management. This is threatening the development of the universities. However, hitherto, the reasons for the said shortfall were not clear. This paper reports on the findings of a study that delved into these reasons, with specific reference to staff recruitment policies and their implementation. It reports that the fairness of the universities' employee recruitment guidelines and the way these are implemented are significantly and positively with the universities' diversity management. The failure to manage staff diversity in a fair manner is attributed to unfairness of some of the universities' recruitment policy guidelines albeit partially; adherence to the guidelines was found to be more significantly related to effectiveness in diversity management. Subsequently, the paper recommends elimination of recruitment guidelines that discriminate against some would be qualifying applicants and strict adherence to the policy guidelines that promote staff diversity.
\end{abstract}

Keywords: Diversity management; Human Resource Management; Governance.

\section{Introduction}

Failure to manage diversity in a fair manner is one of the main challenges facing universities in Uganda (Izama, 2013; Tettey, 2010). This is particularly depicted in the demographic characteristics of these institutions' academic workforce (Ntayi, Beijuka, Mawanga \& Muliira, 2009). As specified in Section 6(3) of the Employment Act of Uganda, 2006, these characteristics include sex, ethnic background and religion. The same Act indicates that all employing organisations in Uganda should build their workforce in a manner that is fair to all qualifying people, irrespective of these demographic attributes. However, realisation of such fairness has eluded most of the universities as is evident in the asymmetrical composition of their workforce. In terms of sex, for instance, 
Hassan (2012) indicates that women are still critically underrepresented in the academic workforce in Central Uganda. This is supported by the National Council for Higher Education (2013), which indicates that the academic workforce of Central Ugandan universities is $87 \%$ male. In terms of ethnicity, the analysis of Makerere University, Kyambogo University, and Mbarara University of Science and Technology staff lists (2010, 2011, 2012 and 2013) reveals that most of these universities' departments are dominated by employees belonging to the same tribe as that of the heads of the departments. The analysis of the religious composition of these universities' academic workforce reveals that on average, it is $94 \%$ Christian and only 6\% Muslim. Religious imbalances are also evident in the academic workforce of most private universities in the region. It is not uncommon to find Catholic, Protestant or Muslim academic employees dominating a university whose foundation body is Catholic, Protestant, or Muslim oriented, respectively, especially at a management level (Namutebi, 2012). This does not mean that there are no women or people of different ethnicities and faiths that are more suitably qualified to be employees in these universities (cf. Mwesigwa, 2014; Lule, 2013; Nabulya, 2013; Ntambaazi, 2013; ActionAid International Central Uganda et al., 2012; World Bank, 2008).

Harvey (2011) suggests that such diversity mismanagement may make the universities lose out on becoming more competitive and successful. It could deny them access to the widest possible pool of skills, abilities, and ideas. It may also limit their chances of building a public image by which they can win full community acceptance and support (Guest \& Shacklock, 2011). When an organisation is sensitive to attributes of diversity that are critical to the community it is serving, it makes people feel fairly treated and this motivates them to respond by supporting it as their own organisation (Kochan et al., 2003). They associate with it as loyal clients, considerate suppliers, supportive lenders, or willing providers of information the organisation requires to understand and respond to the needs of the market in a satisfactory manner (Kochan et al., 2003). This improves the success of the organisation (Karsten, 2006). In contrast, any organisation whose diversity management does not pay attention to the diversity features that the people it serves consider important finds it difficult to succeed. It makes people feel alienated to the extent that they become indifferent to the organisation (Layne, 2002; Wheeler, 2001).

Accordingly, the diversity mismanagement in universities in Central Uganda reported above presents as a significant problem that threatens the universities' development and sustainability. There is need to understand why it exists- to determine what needs to be done to overcome it. However, a gap in knowledge on the subject relates to the fact that most of the writing on the subject is descriptive, presenting information about its prevalence albeit without accounting for the same and what may need to be done to overcome it. This 
study was conducted to fill this gap. Specific attention was paid to staff recruitment policies as an instrument of diversity management in the universities because recruitment policies and the way they are implemented are one of the main means through which organisations manage diversity (Mayhew, 2014; Jeffrey, 2011; Katusiime-Muhwezi, 2010). Four specific research questions were addressed: How do staff of universities in Central Uganda perceive their universities' management of gender, ethnic and religious diversity? How do staff of universities in Central Uganda perceive the fairness of the guidelines prescribed by the universities' recruitment policies? To what extent do universities in Central Uganda implement the guidelines prescribed by their recruitment policies? What is the relationship between the content and implementation of recruitment policies and diversity management in universities in Central Uganda?

\section{Related Literature and Knowledge Gap}

Literature indicates that diversity management is differently defined and approached. However, the definition adopted in this paper is one given by Thomas (2005). Describing diversity as a concept that subsumes all "individual differences that are socially and historically significant and which have resulted in differences in power and privilege inside as well as outside of organizations," Thomas (2005) defined diversity management as "a comprehensive managerial process for developing an environment that works for all people" (p.9). This definition is adopted because of its emphasis on managing diversity according to differences that are socially and historically significant. This emphasis underpins Central Uganda's situation, since the differences stressed in the employment sector of this country are those that are historically and socially significant.

According to the diversity theory of inclusion, an organization needs to balance its workforce in terms of these demographic differences not only because they are historically and socially significant in the labour market; but also because they help to create a workforce that enables the organisation to acquire diverse competences, a better understanding of its market, a public image or reputation that improves its acceptability to the community it serves, and subsequently, improved success in business (Harvey, 2011; Melanie, 2007; Siddall, King, Coleman \& Cotton, 2004). Literature indicates that diversity management can be accomplished through affirmative action, involving application of international and national legislation that promote diversity through non-discrimination (Marlene, 2006). It can also be encouraged through administrative actions intended to promote social justice by focusing on equitable balancing of the workforce according to critical diversity attributes 
(Harvey, 2011; Scott, 2007). Diversity management can also be promoted through the market-driven diversity management approach (Guest \& Shacklock, 2011; Tatli \& Ozbilgin, 2009). This is a business-oriented approach that involves being responsive to the market and therefore focusing on workforce inclusion and acceptance based on sensitivity not to merit alone but also to non-merit demographics that make the workforce a true reflection of the market, especially in terms of socially and historically critical attributes such as sex, ethnicity, sexuality, marital status, race, colour, religion, disability, nationality, and a host of other attributes of employees and potential employees (Flood et al., 2008; Vaughn, 2006). Research has shown that one of the ways by which organisations can promote diversity management involves using recruitment policies (Mayhew, 2014; Jeffrey, 2011).

A recruitment policy refers to the action plan that guides an organisation as to what should be done whenever there is need for recruitment (Tatli \& Ozbilgin, 2009). This policy is made up of guidelines (rules, standards, procedures and practices) stipulated to be followed whenever an organisation such as a university is soliciting, contacting, and raising the interest of suitable candidates to apply for vacant posts (Noeleen, Shaun \& Viney, 2003). It is these guidelines that determine how an organization should identify and attract suitable candidates internally or externally. They therefore have to relate to how diversity is managed in an organisation like a university. Research has shown that the guidelines do not relate directly to diversity management; they do so through their observance by those implementing them (Katusiime-Muhwezi, 2010; Knouse et al., 2008; Tatli \& Ozbilgin, 2009; Taylor, 2009; Thomas, 2005; Eitelberg \& Mehay, 2004; Heather \& Limberger, 2004; Hays-Thomas, 2004; Siddall et al., 2004; Jackson, Joshi \& Erhardt, 2003; Von Bergen, Soper $\&$ Foster, 2002). These studies have, nonetheless, been conducted outside Central Uganda and about organizations that are typically different from universities in general and those in Central Uganda in particular. Consequently, the relationship between recruitment policy guidelines, their observance and diversity management remains to be established as far as Central Ugandan universities are concerned. This study was needed to address the relationship.

In particular, Eitelberg and Mehay (2004) observed that good recruitment policy guidelines should not encourage discrimination against job applicants. They should not encourage advertisement of person specifications that discriminate against men or women applicants, black or white applicants, or against applicants of different religious affiliations. Recruitment policy guidelines should generally not be used to promote any form of non-merit discrimination against potential applicants. These observations suggest that good recruitment policy guidelines are tools for promoting diversity management through minimization of discrimination in an organization. They therefore translate into attracting all job applicants who possess the necessary 
job requirements, irrespective of their gender, tribal, religious and other differences.

Knouse et al. (2008) stressed that recruitment policy guidelines that should be observed for effective diversity management are those that enable organisations to strategically harness the various advantages of diversity, including increased innovativeness, productivity, effectiveness, acceptability and therefore marketability to a wider base of clientele. Tatli and Ozbilgin (2009) concurred with Knouse et al. (2008) when they observed that today, recruitment policy guidelines that promote diversity management are the guidelines that strategic organizations use to tap the benefits of inclusion through recruiting employees irrespective of their gender, being in minority groups, or their geographical location. Heather and Limberger (2004) had earlier on observed that such recruitment has been made possible by the advent of Internet technology. Employees can now be recruited from any part of the globe by just advertising vacant posts via an organization's website.

Zairi (2008) noted that recruitment policy guidelines that promote diversity enable organizations to build a quality workforce through attracting a pool of employees who are innovatively, skilfully, and demographically diverse, and who, therefore are more productive and acceptable to the market. Zairi (2008) observed further that through the use of diversity recruitment policy guidelines, the level of disgruntlement hitherto felt by minority groups as a result of being left out when recruiting employees has considerably declined.

According to Kochan et al. (2003), recruiting a diverse workforce carries with it a tendency establishing good relationships and partnerships as well as a good reputation with communities from which the workforce is drawn. Such advantages help to build a favourable public and global image, which puts an organization in a better position to keep on attracting and retaining more and more of the best talent all over the world, irrespective of the sex, ethnic and religious differences (Kochan et al., 2003). Research has however, shown that using recruitment policy guidelines as tools of diversity management has tended to be challenged by a number of issues. In the first place, it has been observed that for recruitment policy guidelines to succeed in promoting diversity management, they have to be clearly articulate about it (Shackleton, 2007; Scott, 2007). The policy guidelines should clearly state that they are intended to create a diverse workforce based on the rationale of the diversity theory of inclusion (Saunders et al., 2008). They should also encourage market research for purposes of scanning and following up the demographic changes in the market so that the changes can be reflected in the recruited workforce (Sajjad-ur-Rehman \& Marouf, 2008). It has been argued that human resource professionals should make use of the latest market research to diagnose diversity and to reflect it in their organizations' recruitment policy guidelines (Jackson et al., 2003; Von Bergen et al., 2002). 
Unfortunately, not many recruitment policy guidelines are as flexible and responsive to diversity changes in the market as they should (Joshi \& Erhardt, 2003). As a result, the guidelines compromise instead of promoting the changing nature of diversity attributes of the market, which minimizes the chances of an organization to realize a diverse workforce and its associated benefits. Specifically, the method the guidelines prescribe to advertise available vacancies can affect diversity management in a significantly adverse manner (Knouse et al., 2008). Vacancy advertising methods determine whether the information reaches or does not reach all eligible job applicants. These include referrals; contacting and establishing relationships with companies that look for suitable candidates through offering incentives, recognition, and rewards; and connecting with external diverse professional organizations and communities (Siddall et al., 2004). In some organizations, however, the methods prescribed to recruit employees tend to eliminate some potential candidates by leaving them uninformed about the job (see, for example, Vaughn, 2006; Nannono, 2009).

According to Ursell (2009), it is very common to advertise a vacant post and only people of the same tribe, religion or gender apply and emerge as the most suitable for the post. It is also common to find a situation in which the policy guidelines in place to guide recruitment through internal transfers and promotions favour people from the same tribe, religion or gender (Kerslake \& Goulding, 2006). This has been witnessed in the military arm of Central Uganda government as a result of the institution's history. Although administrative diversity management is recommended in such a situation, it has not yielded expected outcomes. Could this also apply to the country's universities as well? The answer requires an empirical investigation; hence the need for this study. After all, the fact that recruitment policy guidelines may fail to guarantee fair diversity management has been supported by Zairi's (2008) research, which shows that more emphasis could be put on recruiting a particular person rather than on the purpose, requirements and demands of the job itself. This tends to occur in organizations where competence and merit recommended by policy are compromised by organisational culture, patronage, nepotism, bribery, corruption, favouritism, or preferential treatment (Saunders et al., 2008). These practices tend to ignore the purpose of the recruitment policy and instead promote the interests of influential persons in the organisation (Palmberg \& Garvare, 2006). In such situations, even when a vacant post is advertised as required by policy, all job applications received in response are simply disposed of in dustbins without even paying attention to whether the applicants are more suitable than the person preferred by influence wielders or not (Ursell, 2009). These observations imply that when a particular candidate is preferred to take up a job, managing diversity based on the prescribed recruitment policy guidelines becomes difficult. It is however not 
clear whether this also happens in universities in Central Uganda; hence the need for this study. Another barrier to the success of a recruitment policy in promoting diversity management is that the educational levels of some groups may be historically so low that the groups cannot favourably compete with other groups (Palmberg \& Garvare, 2006). In fact, research has shown that a policy intent to promote diversity in an organization may be challenged by the fact that not enough qualified people may be obtained from some demographic groups to fill certain positions (Palmer, 2003). Another challenge has been identified as personal preferences and interests. Some people may not be interested in certain jobs even when they qualify for them (Palmer, 2003). This limits recruiting diverse candidates.

In general, literature indicates that through the guidelines they prescribe and how the guidelines are observed, recruitment policies play a role in ensuring that organisations like universities manage diversity in a fair manner as far as sex, ethnic and religious differences of job applicants are concerned. Literature also indicates that the ability of the policies can be compromised when the prescribed guidelines are not observed as a result of interferences such as organisational culture, personal influences of those controlling the recruitment process, and other influences. Notwithstanding, recruitment policy guidelines may be limited in their ability to promote a diverse workforce. A key conclusion from the foregoing literature that relates to the problem of diversity mismanagement in universities in Central Uganda is that part of the problem may be with the policies themselves while part of the problem may be due to the way these policies are implemented. Review of the literature also indicates that, unfortunately, in the case of these universities, information on attributes of both these variables is generally non-existent-apparently because hitherto, research had not been conducted on recruitment policies and diversity management. It is against this background that this study scrutinised these attributes, including the perceptions staff of the universities hold about the same.

\section{$3 \quad$ Methodology}

The study was conducted following a descriptive cross-sectional survey design through which primary data were collected from administrators and academic staff of the selected universities (Table 1).

Table 1: Population and Sample

\begin{tabular}{llll}
\hline Respondents & Population & Sample* $^{*}$ & Respondents \\
\hline University administrators & 96 & 76 & 50 \\
Academic staff members & 136,002 & 384 & 210 \\
Total & 136,098 & 460 & 260 \\
\hline
\end{tabular}

${ }^{*}$ Cited from Krejcie and Morgan (1970) 
Multistage sampling was used to select the sample. This probability sampling technique was used to facilitate selection of a statistically representative sample in a highly cost effective and time-saving manner (Agresti \& Finlay, 2008). The universities in Central Uganda were first clustered into two categories: public and private. The private universities were further categorised into those that are denominational and those that are sponsored by trusts. Subsequently, the lottery method of the simple random sampling technique was used to select universities from each category. Eleven (11) universities, representing 39 percent of the universities in the region were selected. This proportion was greater than the minimum of 30 percent recommended by Saunders et al. (2003) as the sample size required to attain statistical representativeness. In each of the selected universities, convenience sampling was used to select the respondents because it facilitates selection according to the accessibility of respondents (Amin, 2005).

Data was collected using a self-administered questionnaire. The questionnaire elicited responses using a Likert scale of responses stretching from "Strongly Disagree" (1), through "Disagree" (2), "Not Sure" (3), "Agree" (4), to "Strongly Agree" (5). The content validity index and Cronbach Alpha coefficient of the questionnaire were established at .92 and .9 respectively. The data collected was analysed using descriptive statistics, ANOVA, correlation and linear regression analysis.

\section{$4 \quad$ Findings}

The findings are presented according to the objectives of the paper. The first objective was to establish the perceived level of managing sex, ethnic and religious diversity in universities in Central Uganda. Chi Square and ANOVA findings are shown in Table 2.

Table 2: Perception of Diversity Management (Mean Scores, $N=260$ )

\begin{tabular}{|c|c|c|c|c|c|}
\hline Attributes of Diversity Management & $\mathrm{D}$ & $\mathrm{P}$ & $T$ & $\mathrm{~F}$ & Sig. \\
\hline $\begin{array}{l}\text { The university has rules for ensuring that its } \\
\text { academic workforce is balanced }\end{array}$ & 1.05 & 2.01 & 1.61 & 8.11 & .000 \\
\hline $\begin{array}{l}\text { Staffing of the university follows relevant laws } \\
\text { on affirmative action }\end{array}$ & 1.06 & 3.51 & 1.55 & 9.91 & .000 \\
\hline $\begin{array}{l}\text { The university endeavours to balance } \\
\text { attributes of diversity in its workforce }\end{array}$ & 1.19 & 3.55 & 1.63 & 19.01 & .000 \\
\hline $\begin{array}{l}\text { University respects international diversity } \\
\text { management conventions }\end{array}$ & 1.13 & 2.19 & 1.56 & 11.88 & .000 \\
\hline $\begin{array}{l}\text { The university's academic workforce is as } \\
\text { diverse as its the society }\end{array}$ & 1.13 & 2.43 & 1.60 & 15.913 & .000 \\
\hline
\end{tabular}


The levels of significance (Sig.) in Table 2 reveal that all the F-values were significant at the.01 level of significance. This implies that the perception of gender, religious and ethnic diversity management differed significantly across the universities. In particular, the mean distribution reveals that the respondents from private universities "strongly disagreed" on all the indicators of diversity management. This suggests that these universities were not managing diversity appropriately. This distribution indicates further that diversity management was not given attention even in public universities, except in terms of applying laws on affirmative action (mean $=3.51$ ) and making efforts to balance the academic workforce in terms of such diversity attributes considered critical in the region (mean $=3.55)$. However, these mean values were close to ' 4 ', implying that even in these cases, the level of managing this diversity was low. A careful scrutiny of the mean values corresponding to the foundation bodies of the universities points to a similar pattern of interpretation.

Table 3: Fairness of Recruitment Policy Guidelines $(N=260)$

\begin{tabular}{lll}
\hline Recruitment Policy Guidelines & Mean & Std. \\
\hline $\begin{array}{l}\text { The policy requires that no vacant post should be filled } \\
\text { before it is advertised in public media }\end{array}$ & 4.75 & .102 \\
$\begin{array}{l}\text { The university's recruitment policy allows recalling a } \\
\text { retired employee to fill a vacant position }\end{array}$ & 4.75 & .102 \\
$\begin{array}{l}\text { In case the university is recruiting internally, the policy } \\
\text { requires putting up an internal advert informing all } \\
\text { employees about vacancies }\end{array}$ & 4.56 & .132 \\
\hline
\end{tabular}

The mean distribution in Table 3 indicates how employees described the fairness of the guidelines stipulated by their universities' recruitment policies to potential job applicants. Based on the response scale, respondents who "strongly agreed" (mean close to ' 5 ') implied that the guidelines were very fair to potential job applicants. Based on this interpretation, the mean values in Table 3 indicate that respondents "strongly agreed" with all the guidelines. This implies that the universities' recruitment policy guidelines were fair to potential job applicants. However, review of the universities' recruitment policies revealed that their guidelines specified only academic qualifications or competency requirements that an individual needed to occupy a post. The situation was different in one of the denominational universities. In addition to the stipulated merit requirements, the recruitment policy stated that, "All applicants for the post of vice chancellor and deputy vice chancellor should be born again and preferably Anglican." Another policy also belonging to a denominationally founded university required all applicants for the posts of university chancellor and vice chancellor "to be Catholic by faith." These 
findings suggest that some of the universities' recruitment policy guidelines, which administrators and lecturers described as very fair, prescribed guidelines based on non-merit diversity characteristics.

Table 4: Adherence to Recruitment Policy Guidelines $(\mathrm{N}=260)$

\begin{tabular}{|c|c|c|}
\hline Recruitment policy guidelines & Mean & Std. \\
\hline $\begin{array}{l}\text { Vacant posts are advertised as prescribed in the policy } \\
\text { guidelines }\end{array}$ & 1.16 & .048 \\
\hline $\begin{array}{l}\text { Applicants for posts are considered on the merit of their } \\
\text { qualifications }\end{array}$ & 1.16 & .048 \\
\hline $\begin{array}{l}\text { Not only relatives of influential university officials are } \\
\text { recruited in the university }\end{array}$ & 1.51 & .058 \\
\hline The university's recruiting officers work with integrity & 1.99 & .002 \\
\hline $\begin{array}{l}\text { Candidates for positions don't have to be favoured to be } \\
\text { recruited }\end{array}$ & 1.09 & .064 \\
\hline Transfers are done in a legitimate and fair manner & 1.09 & .064 \\
\hline Promotions follow prescribed guidelines & 1.16 & .048 \\
\hline $\begin{array}{l}\text { Majority of the positions are filled in accordance with relevant } \\
\text { guidelines }\end{array}$ & 1.99 & .002 \\
\hline
\end{tabular}

A careful analysis of the distribution of the means reveals that the respondents generally disagreed (the means were close to ' 1 ' or to ' 2 ') with all the items in Table 4. For instance, respondents strongly disagreed that a vacant post was advertised as prescribed by policy not after a person to fill it had already been identified through the personal influence of the top officials in the unit (mean = 1.35 , Std. $=.057$ ). This implies that vacancies were advertised after being filled. In the same way, the findings in Table 4 indicate that the recruitment policy guidelines prescribed by the selected universities were perceivably not observed whenever recruitment took place. This was further substantiated when respondents were asked to comment on whether their universities' recruitment policies served their intended purpose as expected. One of the respondents said that:

To some employees the policy is followed and it indeed serves its purpose. To others, it is completely violated and the purpose is compromised. You see, some of my colleagues here smuggled their way in. It is not clear how they came in. So, serving its purpose or not depends on who is assessing it and how he or she was recruited. It also depends on how an employee views what goes on in their departments as far as recruiting employees is concerned. In general, it can serve its purpose if those recruiting do not have anyone in mind to fill the vacancy. 
One administrator responded thus:

I highly doubt whether the intention of our recruitment policy is realized as expected. In fact, it is abused by the top administration to the extent that I cannot believe what is going on. It appears the recruitment policy was abandoned a long time ago. Employees here are recruited according to desires of one big boss. It is all a one man's exercise. We just see new employees being recruited.

Another administrator made the following comment:

Don't even talk about serving the intended purpose. When you read what the policy states and compare it with what goes on here, you conclude straight away that the policy is not followed. Employees are recruited according to bosses' wishes...

Yet another one said:

No comment. I am just sick of what is going on here. How can you talk about a (recruitment) policy serving its purpose when we have people from one tribe here? Which policy stipulates such a purpose? I need to be educated on this.

The findings above suggest that the observance of guidelines stipulated by the recruitment policies of the selected universities left a lot to be desired.

Table 5 shows that the correlation coefficient for the relationship between the fairness of recruitment policy guidelines and diversity management was positive $(r=.198)$ and significant.

Table 5: Relationship between Recruitment Policy and Diversity Management

\begin{tabular}{|c|c|c|c|c|}
\hline Variables & Statistics & $\begin{array}{l}\text { Fairness of } \\
\text { recruitment } \\
\text { policy guidelines }\end{array}$ & $\begin{array}{l}\text { Implementation } \\
\text { of recruitment } \\
\text { policy guidelines }\end{array}$ & $\begin{array}{l}\text { Diversity } \\
\text { management }\end{array}$ \\
\hline $\begin{array}{l}\text { Fairness of } \\
\text { recruitment } \\
\text { policy guidelines } \\
\text { Implementation } \\
\text { of recruitment } \\
\text { policy guidelines } \\
\text { Diversity } \\
\text { management }\end{array}$ & $\begin{array}{l}\text { Pearson }(r) \\
\text { Sig. } \\
N \\
\text { Pearson }(r) \\
\text { Sig. } \\
N \\
\text { Pearson (r) } \\
\text { Sig. } \\
N\end{array}$ & $\begin{array}{l}1 \\
. \\
260 \\
.481^{* *} \\
.000 \\
260 \\
.198^{*} \\
.001 \\
260\end{array}$ & $\begin{array}{l}1 \\
. \\
260 \\
.439^{* *} \\
.000 \\
260\end{array}$ & $\begin{array}{l}1 \\
.\end{array}$ \\
\hline
\end{tabular}

** Significant at the 0.01 level, *Significant at the 0.05 level

The correlation $(r=.439)$ between observance of the recruitment policy guidelines and the level of managing this diversity was also positive and 
significant. After establishing that positive relationships existed between these variables, linear regression analysis was conducted to determine whether the relationship was predictive (Table 6).

Table 6: Diversity management by fairness and implementation of recruitment policy guidelines

$$
\text { Diversity Management }
$$

Std.

Std. $\quad$ Adjusted the of

\begin{tabular}{|c|c|c|c|c|c|}
\hline Predictors & Error & B & $\mathrm{t}$ & Sig. $R^{2} \quad R^{2}$ & F $\quad$ Sig. estimate \\
\hline Constant & .105 & & 8.817 & .000.609.607 & 59.755 .000 .006 \\
\hline $\begin{array}{l}\text { Fairness of } \\
\text { recruitment } \\
\text { policy } \\
\text { guidelines }\end{array}$ & .045 & .077 & 0.705 & .570 & \\
\hline $\begin{array}{l}\text { Implementation } \\
\text { of recruitment } \\
\text { policy } \\
\text { guidelines }\end{array}$ & .089 & .708 & 21.115 & .000 & \\
\hline
\end{tabular}

The level of significance in Table 6 indicates the corresponding F-value $(\mathrm{F}=$ 59.755) was significant at the .01 level of significance $($ Sig. $=.000<.01$ ). Therefore, the corresponding Adjusted R-Square value of .607 indicates that both the fairness and observance of the guidelines stipulated by the recruitment policies of the universities that participated in the study predicted the level of sex, ethnic and religious diversity by a significant $60.7 \%$. This implies that the fairness and observance of these guidelines determined the level of diversity management in Central Uganda's universities in a significant manner. In terms of individual predictors however, the fairness of the guidelines was not a significant predictor $($ Beta $=.077, \mathrm{t}=0.705$, Sig. $=.570>.05)$. Only the observance of these guidelines predicted the level by a significant $70.8 \%$ (Beta $=.708, \mathrm{t}=21.115$, Sig. $=.000<.01)$. These findings indicate that the level of diversity management realised in Central Ugandan universities depended much more on the observance than on the fairness of the guidelines stipulated by the universities' recruitment policies.

\section{Discussion, Conclusion and Recommendations}

Findings indicate that the fairness and observance of the guidelines stipulated by recruitment policies of universities in Central Uganda related with the 
universities' level of managing sex, ethnic and religious diversity in a significant, positive and predictive manner (Table 5 and Table 6). The findings, therefore, concur with the observations made by Knouse et al. (2009), Tatli and Ozbilgin (2009) and Taylor (2009). Each of these scholars came to a conclusion that the extent to which a diverse workforce is promoted or minimized in an organization is significantly determined by the nature of the guidelines stipulated by recruitment policies and how these guidelines are observed. The established relationship indicates that this was largely the case in the universities that participated in the study. The positive nature of the relationship reveals that the level at which sex, ethnic and religious diversity was managed varied in the same direction with the level of fairness and observance of the guidelines stipulated by the universities' recruitment policies. In other words, if the guidelines were highly fair to potential job applicants and if they were observed as stipulated, they translated into high levels of managing sex, ethnic and religious diversity, and vice versa. Therefore, the low to negligible levels of managing this diversity (Table 2) imply that there was something not right with the fairness and observance of the guidelines.

The findings in Table 3 indicate that the guidelines were generally very fair to potential job applicants. This would suggest that the fairness of the recruitment guidelines did not explain the low level of sex, ethnic and religious diversity in the universities. However, document analysis revealed that some of the universities' recruitment policies entailed guidelines that were unfair to all potential job applicants. The unfairness was in terms of fixing religious affiliations of applicants to particular jobs, especially those at the senior or top management level. Obviously, this unfairness was discriminatory as it could make some of the would-be competently right persons not to be considered for the jobs. It is therefore the kind that led the fairness of the guidelines to relate positively and significantly with the low levels of managing sex, ethnic and religious diversity in the universities (Table 5). It is worth noting that the fact that the relationship was weak and not significantly predictive (Table 6) suggests that the unfairness of the guidelines was not a strong contributor to the negligible management of sex, ethnic and religious diversity in the universities.

Accordingly, the strong predictive and positive relationship that the observance of the guidelines had with the level of managing sex, ethnic and religious diversity (Table 5 and Table 6) effectively implies that it is this observance that accounted for the low to negligible levels of this managing management. This is substantiated by the findings in Table 2 and Table 4 . The findings in Table 2 indicate that the management of this diversity varied between low and negligible levels. The findings in Table 4 indicate that whenever recruitment took place, the universities' recruitment guidelines were not observed as stipulated. Clearly, not observing the guidelines that were perceivably very fair to potential job applicants (Table 3) translated into 
negligible diversity management (Table 2). Further substantiation of this argument is derived from the qualitative findings. These findings also revealed that instead of following the guidelines, recruitment of employees was largely according to the wishes, desires and personal contacts of the top administrators or those in charge of the recruitment exercise. Not much attention was paid to following the guidelines.

The findings indicate that the failure to manage sex, ethnic and religious diversity in Central Ugandan universities is partly explained by the unfairness of some of the recruitment policy guidelines that discriminate against job applicants based on religious affiliation. This failure is also significantly explained by the fact that instead of following the non-discriminatory guidelines as stipulated in the universities' recruitment policies, recruitment of employees follows wishes, desires, influences and personal contacts and relationships that senior university administrators and those in charge of the recruitment process have with job applicants.

Therefore, it is recommended that the management of the universities in Central Uganda improves the management of diversity by: 1) eliminating recruitment guidelines that discriminate against potential job applicants on account of their religious affiliations; and 2) ensuring that the universities' nondiscriminatory recruitment policy guidelines are implemented.

\section{References}

ActionAid International Central Uganda (AAU), Development Research and Training (DRT), Central Uganda National NGO Forum (UNNGOF). (2012). Lost opportunity? Gaps in youth policy and programming in Central Uganda. [Online]. Retrieved on December 20, 2014 from http://www.actionaid.org/sites/files/actionaid/youthrepot-final_0.pdf

Agresti, A., \& Finlay, B. (2008). Statistical options for the social science $\left(4^{\text {th }}\right.$ Ed.). Upper Saddle River, NJ: Prentice Hall.

Amin, M. (2005). Social science research: Conception, methodology and analysis. Kampala: Makerere University Printery

Central Uganda Bureau of Statistics (2013). Statistical abstract. [Online] Retrieved on December 21, 2014 from http://www.ubos.org/onlinefiles/uploads/ubos/pdf\%20documents/abstracts/St atistical\%20Abstract\%202013.pdf

Eitelberg, M. J., \& Mehay, S. L. (2004). Recruitment in the twenty first century: What to include in the policy. International Journal of Educational Management, 1 (4): 21-34. 
Field, A. P. (2005). Reliability analysis, discovering statistics using SPSS (2 ${ }^{\text {nd }}$ Ed.). London: Sage.

Flood, R. L., Norma, R., \& Romm, A. (2008).Diversity management: Theory in action. Retrieved March 23, 2009 from http://www.springerlink.com/institutional-login.aspx/content.

Guest, R., \& Shacklock, K. (2011). The impending shift to an older mix of workers: perspectives from the management and economics literature. International Journal of Organisational Behaviour, 10 (3): 713-728

Harvey, C.P. (2011). Understanding and managing diversity. New Jersey: Pearson Education, Inc.

Hassan, A. (2012). Career development among women academicians: A case study in selected Universities in Central Uganda. Institute of Education, International Islamic University Malaysia (PhD thesis). [Online]. Retrieved on December 21, 2014 from http://lib.iium.edu.my/mom2/cm/content/view/view.jsp?key=zaT9IJozX4hc K7IajYdSUBpWq5cJYfJZ20140129152734452

Hays-Thomas, R. (2004). Why now? The contemporary focus on managing diversity. In M. S. Stockdale \& F. J. Crosby (Eds.). The psychology and management of workplace diversity (pp. 3-30). Malden, MA: Blackwell.

Heather, C., \& Limberger, J. (2004). Can an organization adopt an online recruitment policy: Cross-cultural recruitment? Journal of European Industrial Training, 5 (28), 14-29.

Izama, K.V.S. (2013). Managing diversity in African Universities: Living and challenging difference on four Central Ugandan campuses. Pluralism Working Paper No. 11. [Online]. Retrieved on December 20, 2014 from http://www.uvh.nl/uvh.nl/up/ZwtndrvIyB_PWP_no_11_Managing_Diversity _in_African_Universities.pdf

Jackson, S. E., Joshi, A., \& Erhardt, N. L. (2003). Recent research on team and organizational diversity: SWOT analysis and implications. Journal of Management, 29: 801-830.

Jeffrey, B. (2011). Good practice guide: Diversity in recruitment to the SCS. [Online]. Retrieved on December 20, 2014 from http://www.civilservice.gov.uk/wpcontent/uploads/2011/09/20091207GoodPracticeGuideDiversityinRecruitme nttotheSCS_tcm6-35296.pdf

Karsten, M. F. (2006). Management, gender and race in the 21st century. New York: University Press of America.

Katusiime-Muhwezi, M. (2010). Recruitment, selection procedures and employee retention in private universities in Uganda: A case study of Kampala international university. Makerere University: Unpublished master of org. Psycho thesis. 
Kerslake, E., \& Goulding, A. (2006). Recruitment and equal opportunities, Librarian Career Development, 3 (7): 39-51.

Knouse, S.B., Alvin, J., Smith, P., \& McDonald, D.P. (2008). Issues in diversity management. Internal Report Number 05-08. Defence Equal Opportunity Management Institute

Kochan, T., Bezrukova, K., Ely, R., Jackson, S., Joshi, A., John, K., Leonard, J., Levine, D., \& Thomas, D. (2003). The effects of diversity on business performance: Report of the diversity research network. Human Resource Management, 42: 3-21.

Krejcie, R. V., \& Morgan, D. W. (1970). Determining sample size for research activities. Educational and Psychological Measurement, 30, 607-610.

Layne, P. (2002). Best practices in managing diversity. Leadership and Management in Engineering, 2: 28-30.

Lule, J.A. (2013). 62\% of Central Ugandan youth are jobless. [Online]. Retrieved on December 10, 2014 from http://www.newvision.co.ug/news/639446-62-of-central Ugandan-youthjobless--report.html

Makerere University (2005-2008). Makerere University Employee Enrolment Lists, 2005, 2006, 2007, 2008. Makerere University: Unpublished.

Mayhew, R. (2014). How does a diversity recruitment policy work for companies? [Online]. Retrieved on December 20, 2014 from http://smallbusiness.chron.com/diversity-recruitment-policy-workcompanies-12025.html.

Melanie, P. (2007) University organizations still not capitalizing on workplace diversity. Women in management review, 8(22):8-17.

Mwesigwa, A. (2014). Central Uganda's unemployed graduates held back by skills gap. [Online]. Retrieved on December 14, 2014 from http://www.theguardian.com/global-development/2014/jan/16/central Uganda-unemployed-graduates-held-back-skills-gap

Nabulya, R. (2013). Youth unemployment rate hits 80\%. [Online]. Retrieved on December 14, 2014 from http://chimpreports.com/index.php/specialreports/14509-youth-unemployment-rate-hits-80.html

Namutebi, E. (2012). Employee procurement and training policies and diversity management in universities in Central Uganda. Makerere University: Unpublished $\mathrm{PhD}$ dissertation.

Nannono, V. (2009). Improving employee effectiveness in Central Uganda national examinations board through human resource acquisition and deployment. Makerere University: Unpublished MBA Dissertation.

National Council for Higher Education. (2013). The state of higher education and training in Central Uganda 2012: A report on higher education delivery and institutions. Kampala: National Council for Higher Education. 
Noeleen, D., Shaun, T., \& Viney, C. (2003). A positive policy? Corporate perspectives on redundancy and out placement. Personnel Review, 7 (22), 315. Retrieved July 5, 2009 from http://www.emeraldinsight.com.

Ntambaazi, W.G. (2013). View point: $83 \%$ youth unemployment is a time bomb! [Online]. Retrieved on December 17, 2014 from http://www.observer.ug/index.php?option=com_content\&view=article\&id=1 9358:view-point-83-youth-unemployment-is-a-time-bomb

Ntayi, J.M., Beijuka, R., Mawanga, F., \& Muliira, (2009). Perceived Workplace discrimination, Instrumental Ethical climate, psychological wellness and task performance. E-Journal of Business and Economic Issues, 4(1): 1-27. [Online]. Retrieved on December 20, 2014 from http://www.mubs.ac.ug/procdocs/Moral\%20Distress/Ntayi\%20workplace\%2 Odiscrimination\%20paper.pdf

Palmberg, L. A., \& Garvare, W. F. (2006). Diversity management in practice. International Journal of Contemporary Hospitality Management, 6 (11): 1933.

Palmer, A., \& Bradley, N. (2006). Developing diversity in SMEs: Collaboration between a city, a business school and employers. Social Responsibility Journal, 2 (2): 26-39.

Sajjad-ur-Rehman, A., \& Marouf, L. (2008). Top-down approach to diversity management. Development and Learning in Organizations, 5(22):20-31.

Saunders, M., Lewis, P., \& Thornhill, A. (2003). Research methods for business students ( $3^{\text {rd }}$ Ed.). London: Prentice Hall.

Saunders, M., Mann, R., \& Smith, R. (2008). Following employee strategic initiatives right from recruitment: A framework of leading practices. International Journal of Operations \& Production Management, 11 (28): 132-145.

Scott, P. (2007). The difference: How the power of diversity creates better groups, firms, schools, and societies. Princeton, N.J.: Princeton University Press.

Shackleton, J. (2007). Employee recruitment: Implications for training policies and diversity management in organizations. International Journal of Educational Management, 1 (6): 9-21.

Siddall, K. King, H., Coleman, T., \& Cotton, B. (2004). Nature of diversity in organizations. Journal of Executive Development, 3 (7): 9-17.

Tatli, A., \& Ozbilgin, M. (2009). Understanding Diversity Managers' Role in Organizational Change: Towards a Conceptual Framework. Canadian Journal of Administrative Sciences, 5 (26), 244-258.

Taylor, C. (2009). The multicultural organization. Academy of Management Executive, 5 (2), 34-47.

Tettey, W.J. (2010). Challenges of developing and retaining the next generation of academics: Deficits in academic staff capacity at African 
universities. [Online]. Retrieved on December 18, 2014 from http://www.foundation-partnership.org/pubs/pdf/tettey_deficits.pdf

The Employment Act, 2006. [Online]. Retrieved on December 21, 2014 http://www.mglsd.go.ug/wpcontent/uploads/2013/07/Laws/employment\%20Act\%202006.pdf

Thomas, D.A., \& Ely, R. (2014). Making differences matter: A new paradigm for managing diversity. [Online]. Retrieved on December 21, 2014 from https://hbr.org/1996/09/making-differences-matter-a-new-paradigm-formanaging-diversity

Thomas, K.M. (2005). Diversity dynamics in the workplace. Belmont, CA: Thomson Wadsworth.

Ursell, R. (2009). Diversity management in corporate America. [Online]. Retrieved December 24, 2014 from http://www.wjh.harvard.edu/ dobbin/cv/articles/2007_Contexts_ursell_robe rt.pdf

Vaughn, B. (2006). High impact diversity consulting. San Francisco: Diversity Training University International Publications Division. Retrieved July 3, 2006 from http://www.dtui.com/consultbkadva11.html.

Von Bergen, C. W., Soper, B., \& Foster, T. (2002). Unintended negative effects of diversity management. Public Personnel Management, 31: 239-252.

Wheeler, M. L. (2001). The diversity executive: Tasks, competencies, and strategies for effective leadership. Report R-1300-01-CR. New York: The Conference Board.

World Bank. (2008). African development indicators 2008/2009. Washington, DC: World Bank.

Zairi, W. (2008). Popularity of diversity management programs. [Online]. Retrieved December 15, 2009 from http://ww w.wjh.harvard.edu/ dobbin/cv/articles/2007_Contexts_zairi _walter.pdf. 